Available online on 15.04.2020 at http://jddtonline.info
Open Access to Pharmaceutical and Medical Research
und $2011-18$, publisher and licensee JDDT, This is an Open Access article which permits
undricted non-commercial use, provided the original work is properly cited

Open@Access

Research Article

\title{
Phytochemical Screening and Antioxidant Activities of Different Organic Extracts of Three Algerian Plants
}

\author{
Maria Rezzoug1, Boulanouar Bakchiche ${ }^{1 *}$, Abdelaziz Gherib ${ }^{1}$, Ouahid Elasri² \\ ${ }^{1}$ Laboratory of Process Engineering, Faculty of Technology, Laghouat University, Laghouat, Algeria \\ 2 Biochemistry and Biotechnology Laboratory, Mohammed First University, Oujda, Morocco
}

\begin{abstract}
We compared the phytochemical constituents and antioxidant activities of three important species of Lamiaceae in Algeria (Mentha spicata Ocimum basilicum and Thymus algeriensis). We noticed that the $M$. spicata species contains the largest fraction of phenolic and flavonoid products (231 and $22 \mathrm{mg} / \mathrm{g}$ ) than the other two species studied. Other hand we founded that the two species M. spicata and T. algeriensis show excellent antioxidant activity in the ethanolic extract according to the two tests (DPPH and ABTS) compared to the ascorbic acid of reference. But the specie 0 . basilicum has good antioxidant activity in aqueous extraction. This Lamiaceae family takes an important place in the lives of Algerians citizens, so this species are very good source of natural antioxidant compounds in algerian traditional medicine.
\end{abstract}

Keywords: Antioxidant activity, Lamiaceae, Mentha spicata, Ocimum basilicum and Thymus algeriensis, DPPH.

Article Info: Received 07 Feb 2020; Review Completed 24 March 2020; $\quad$ Accepted 31 March 2020; $\quad$ Available online 15 April 2020

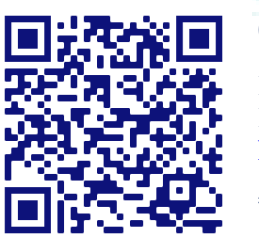

Cite this article as:

Rezzoug M, Bakchiche B, Gherib A, Elasri O, Phytochemical Screening and Antioxidant Activities of Different Organic Extracts of Three Algerian Plants, Journal of Drug Delivery and Therapeutics. 2020; 10(2-s):75-79 http://dx.doi.org/10.22270/jddt.v10i2-s.4038

Boulanouar Bakchiche, Laboratory of Process Engineering, Faculty of Technology, Laghouat University, Laghouat, Algeria

\section{INTRODUCTION}

In African countries such as Algeria, the traditional medicine by herbal treatment takes an important place in the lives of citizens. Traditional medicine uses plants for both their curative and their preventive properties. The medicinal herbal have a use of various phytochemical or the bioactive compounds. The consumption of this vegetable containing antioxidants has been found to offer protection against these diseases.[1] This phytochemicals species also known as secondary metabolites, natural plant constituents present in all plant parts which are responsible for medicinal properties of plants. [2] Among the medicinal plants in Algeria found the Lamiaceae family. This species is one of the largest and most distinctive families of flowering plants; It contains about 236 genera and more than 6000 species. [3] It is one of the most diverse and widespread plant families in terms of ethno medicine.[4]

The Lamiaceae family are valuable in cosmetic, flavoring, fragrance, perfumery, pesticide, and pharmaceutical industries.[5]Several researchers consider this family among medicinal herbal because it is has Phytochemicals present in plants are important as they may determine the medicinal value posed by the plants. These phytochemicals are categorized into two main sets namely primary and secondary. [6,7] The primary consists of amino acids, proteins, sugars and the secondary comprises the alkaloids, flavonoids, tannins, terpenoids, saponin and others. Majority of the phytochemicals have been known to exert valuable therapeutic and pharmacological effects such as insecticidal, bactericidal, fungicidal, anti-parasitic, anti-constipative and probable antiviral effects .[8]

In this work, we determined the phytochemical constituents and antioxidant activities of three important species of Lamiaceae in Algeria (Menthas picata, Ocimum basilicum and Thymus algeriensis).

\section{MATERIALS AND METHODS}

\section{1. The plants}

The whole aerial parts of the study plants including Mentha spicata, Ocimum basilicum and Thymus algeriensis were collected from its natural habitats from Laghouat region (Fig.1\& 2) between the months on April and June, 2017. The plants were authenticated at the Department of Agronomy, Faculty of Science, University of Laghouat. The plant material was air-dried for 15 days and stored at room temperature without exposure to direct sunlight. 

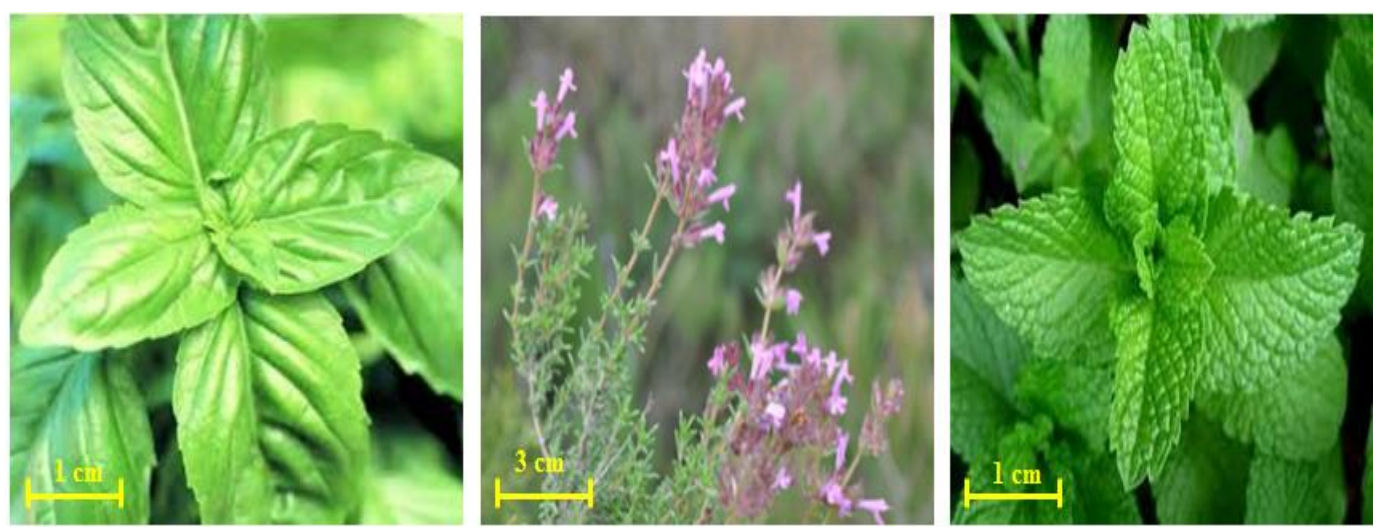

Fig. 1: The three plants studied in this work.

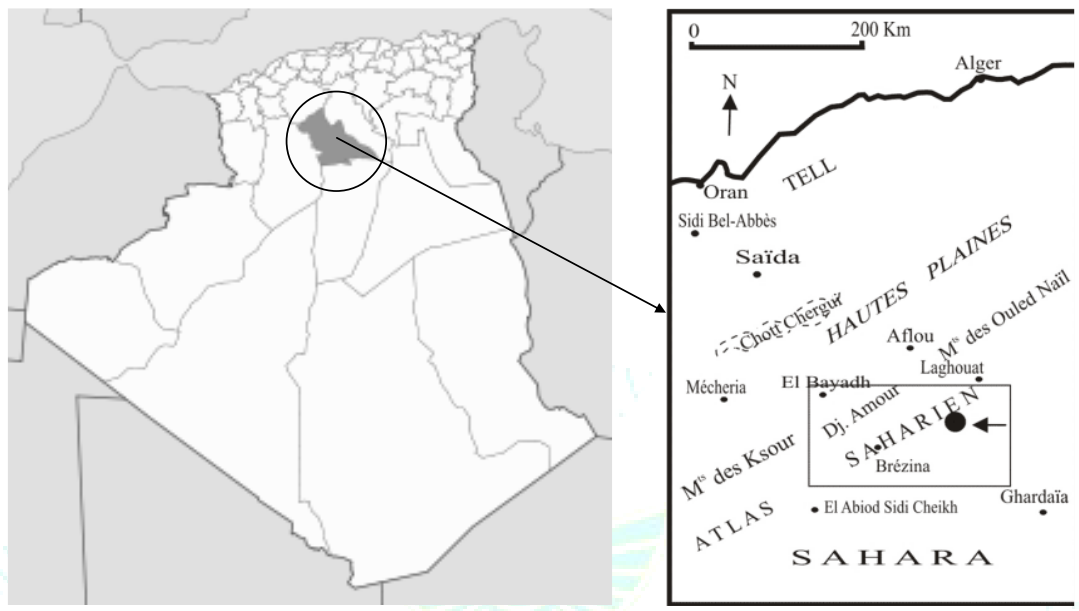

Fig. 2: Map of the sampling area.

\subsection{Preparation of different extracts:}

Aerial parts of M. spicata, O. basilicum and T. algeriensis were prepared by sequential extraction method using four organic solvents in the basis of polarity of solvents (Chloroform, Ethyl acetate, Ethanol and Aqueous). $10 \mathrm{~g}$ of the aerial parts sample was taken in a conical flask and $100 \mathrm{ml}$ of chloroform solvent. The conical flask was kept on mechanical shaker for 24 hours, after that the extract was filtered through whattman filter paper. The dried extract was recovered and stored in refrigerator for further use. Percent of Yield was calculated as follows:

$$
\begin{aligned}
& \text { Extract yield } \\
& =\frac{\text { Weight of the dry extract }(\mathrm{g})}{\text { Weight of the sample used for the extraction }(\mathrm{g})} \times 100
\end{aligned}
$$

\subsection{Phytochemical Screening}

Preliminary qualitative tests were carried out on the foregoing prepared extracts following the method of Harbone ${ }^{[9]}$ for the presence of various classes of compounds such as compounds phenolic, flavanoids, tannins, alkaloids, saponins, carbohydrates, steroids and proteins.

\subsubsection{Determination of Total Phenol Content}

In a test tube, $200 \mu \mathrm{l}$ of the extract was mixed with $1 \mathrm{ml}$ of Folin-Ciocalteu reagent and $800 \mu$ l of sodium carbonate (7.5\%). After shaking, it was kept for $30 \mathrm{mn}$ reaction time. The absorbance was measured at $750 \mathrm{~nm}$. Using gallic acid monohydrate, standard curve was prepared and linearity was obtained in the range of $10-100 \mu \mathrm{g} / \mathrm{ml}$. using the standard curve, the total phenol content was obtained. The total phenol content was expressed as gallic acid equivalent in $\mathrm{mg} / \mathrm{g}$ of the dry weight. All measurements were carried out in triplicates. [10]

\subsubsection{Determination of total flavonoid content}

Total flavonoid content was determined by aluminum chloride method. $1 \mathrm{ml}$ of the extract was mixed with $1 \mathrm{ml}$ $\mathrm{AlCl}_{3}(2 \%)$. After incubation at room temperature for $15 \mathrm{~min}$, the absorbance of the reaction mixture was measured at 415 $\mathrm{nm}$. All determinations were carried out in triplicates. Using rutin, standard curve was prepared and linearity was obtained in the range of $1-10 \mu \mathrm{g} / \mathrm{ml}$. The total flavonoid content was expressed as rutin equivalent in $\mathrm{mg} / \mathrm{g}$ of the dry weight. [10]

\subsubsection{Determination of antioxidant activity by DPPH radical}

The free radical scavenging activity of solvent extracts, based on the scavenging activity of the stable 1,1-diphenyl2-picrylhydrazyl (DPPH) free radical was determined by the method described by Boulanouar [10]. DPPH solution $(0.004 \%)$, plant extracts, and standard (Ascorbic acid) solution were prepared in methanol. Plant extracts and standard (Ascorbic acid) solution were prepared in different concentrations $10,20,40,60,80$, and $100 \mu \mathrm{g} / \mathrm{ml}$. $1.9 \mathrm{ml}$ of different concentrations of standard solution or plant extracts was taken in different test tubes and then $0.1 \mathrm{ml}$ of DPPH $(0.004 \%)$ solution was added and kept in dark for 30 min. Moreover, absorbance was recorded at $517 \mathrm{~nm}$. The decrease in absorbance of the DPPH radical caused by antioxidant was due to the scavenging of the radical by hydrogen donation. It was visually noticeable as a color change from purple to yellow. The percentage inhibition activity was calculated using the formulae below: 
DPPH scavenging activity $(\%)=\left[\frac{A_{0}-A_{01}}{A_{0}}\right] \times 100$

$A_{0}$ is the absorbance of the control reaction

$\mathrm{A}_{1}$ is the absorbance in the presence of the sample of the extracts.

\subsubsection{Determination of antioxidant activity by ABTS radical scavenging}

The scavenging activity of extracts against ABTS radical was determined by following the method described by Boulanouar [10]. Briefly the stock solutions of 7 mM ABTS and $2.4 \mathrm{mM}$ potassium persulphate $\left(\mathrm{K}_{2} \mathrm{~S}_{2} \mathrm{O}_{8}\right)$ in equal volumes were allowed to stand in the dark for 12-16 $\mathrm{h}$ at room temperature. Prior to assay, ABTS solution was diluted in ethanol to give an absorbance of $0.700 \pm 0.02$ at $734 \mathrm{~nm}$. 2 $\mathrm{ml}$ of the resulting solutions was allowed to react with $200 \mu \mathrm{l}$ of the plant extracts with different concentrations, reaction mixture was vortexed and absorbance was measured at 734 $\mathrm{nm}$ after $30 \mathrm{~min}$. The same was done for the ascorbic acid standard of various concentrations $(1-100 \mu \mathrm{g} / \mathrm{ml})$. The amount of sample necessary to decrease the absorbance of ABTS by $50 \%\left(\mathrm{IC}_{50}\right)$ was calculated graphically.

\section{RESULTS AND DISCUSSION}

\subsection{Comparison of extraction characteristics}

We noticed that each plant species reacted differently with the extraction solvents. $M$. spicata has an excellent extraction with ethanol $(21.8 \%)$ against 0 . basilicum and T. algeriensis show significant water extraction (15.8 and 18.4\%) respectively (Tab.1). This result shows that $M$. spicata has chemical constituents soluble in ethanol. On the other hand, $O$. basilicum and T. algeriensis have water-soluble constituents. As well as for three species, the extraction with ethyl acetate is too small, it does not exceed 6\%, which shows that these plant species contains a small fraction soluble in this solvent.

Tab. 1: Comparison of different types of extraction characteristics.

CE: Chloroform extract, EAE: Ethyl acetate extract, EE: Ethanol extract, AE: Aqueous extract

\begin{tabular}{|c|c|c|c|c|c|c|c|c|c|}
\hline & \multicolumn{3}{|c|}{ M. spicata } & \multicolumn{3}{c|}{ O. basilicum } & \multicolumn{3}{c|}{ T. algeriensis } \\
\hline & $\begin{array}{c}\text { Physical } \\
\text { nature }\end{array}$ & Color & $\begin{array}{c}\text { Yield } \\
(\% \mathrm{w} / \mathrm{w})\end{array}$ & $\begin{array}{c}\text { Physical } \\
\text { nature }\end{array}$ & Color & $\begin{array}{c}\text { Yield } \\
(\% \mathrm{w} / \mathrm{w})\end{array}$ & $\begin{array}{c}\text { Physica } \\
\text { l nature }\end{array}$ & $\begin{array}{c}\text { Color } \\
(\% \mathrm{w} / \mathrm{w})\end{array}$ \\
\hline CE & $\begin{array}{c}\text { Semi } \\
\text { solid }\end{array}$ & Green & $6.8 \pm 0.2$ & $\begin{array}{c}\text { Semi } \\
\text { solid }\end{array}$ & Green & $4.2 \pm 0.2$ & $\begin{array}{c}\text { Waxy } \\
\text { solid }\end{array}$ & Green & $11.6 \pm 0.5$ \\
\hline EAE & Solid & Green & $2.2 \pm 0.1$ & Solid & Green & $5.4 \pm 0.2$ & Solid & Grean & $5.6 \pm 0.2$ \\
\hline EE & $\begin{array}{l}\text { Waxy } \\
\text { solid }\end{array}$ & Green & $21.8 \pm 0.5$ & Solid & Green & $10.6 \pm 0.5$ & Solid & Grean & $8.2 \pm 0.2$ \\
\hline AE & Solid & Brown & $11.8 \pm 0.5$ & $\begin{array}{c}\text { Waxy } \\
\text { solid }\end{array}$ & Brown & $15.8 \pm 0.5$ & Solid & Brown & $18.4 \pm 0.5$ \\
\hline
\end{tabular}

\subsection{Comparison of phytochemical tests}

Phytochemical tests show that the three plant species studied do not contain alkaloids and proteins in the four extracts. Thus, these species contain only five chemical groups (Tannins, flavonoids, saponins, steroids and carbohydrates) but with different contents and in different solvents (Tab.2) for this we have adopted a separate approach to facilitate the analysis and development of each species.

Tannins are present in all extracts with the exception of $T$. algeriensis which does not contain them in the EC and EAE extracts. The three plants present only the saponins in the aqueous extracts with significant amounts of these chemical elements in two species M. Spicata and T. algeriensis. Steroids are present in ethanolic extract with average amounts in all three species but $O$. basilicum has a small fraction in the aqueous extract. The three species contain a small amount of carbohydrates but the 0 . basilicum species has a moderate amount in their aqueous extract. Finally, flavonoids are excreted in average amounts by ethanol in the three species. Finally, we have noticed also that 0 . basilicum has a significant extraction of the chemical elements in water whereas the two species M. Spicata and T. algeriensis show a significant extraction in ethanol.

Tab. 2: Comparison of phytochemical tests of this three species plants.

CE: Chloroform extract, EAE: Ethyl acetate extract, EE: Ethanol extract, AE: Aqueous extract +++ = High ; ++ = Moderate ; + = Low; - = Absence

\begin{tabular}{|c|c|c|c|c|c|c|c|c|c|c|c|c|}
\hline \multirow{3}{*}{$\begin{array}{c}\text { Phytochemicals } \\
\text { tests }\end{array}$} & \multicolumn{12}{|c|}{ Plants Extracts } \\
\hline & \multicolumn{4}{|c|}{ M. spicata } & \multicolumn{4}{|c|}{ O. basilicum } & \multicolumn{4}{|c|}{ T. algeriensis } \\
\hline & $\mathrm{CE}$ & EAE & $\mathrm{EE}$ & $\mathrm{AE}$ & $\mathrm{CE}$ & EAE & EE & $\mathrm{AE}$ & $\mathrm{CE}$ & EAE & $\mathrm{EE}$ & $\mathrm{AE}$ \\
\hline Tannins & + & + & +++ & + & + & ++ & +++ & +++ & - & - & +++ & +++ \\
\hline Alkaloids & - & - & - & - & - & - & - & - & - & - & - & - \\
\hline Flavonoids & - & + & ++ & - & - & - & + & + & - & + & ++ & - \\
\hline Saponins & - & - & - & +++ & - & - & - & + & - & - & - & +++ \\
\hline Steroids & - & - & ++ & - & - & - & ++ & + & - & - & ++ & - \\
\hline Carbohydrates & - & - & + & - & - & - & + & ++ & - & - & + & - \\
\hline Proteins & - & - & - & - & - & - & - & - & - & - & - & - \\
\hline
\end{tabular}




\subsection{Comparison of total phenolic and flavonoid content}

When comparing the levels of phenol and flavonoids in the three species, we noticed that the M. spicata species contains the largest fraction of phenolic and flavonoid products (231 and $22 \mathrm{mg} / \mathrm{g}$ ) than the other two species studied (Fig. 3\&4). As well as, the high levels are recorded in the ethanolic extraction for M. spicata and T. algeriensis against for the species 0 . basilicum, it is the aqueous extraction which recorded the strongest extraction of phenols and flavonoids.

These results are correlated with the previous results of the determination of extraction yields and photochemical tests where we found that M. spicata contains a high yield and the extraction of the five chemical elements (tannins, flavonoids, saponin, steroid and carbohydrate) in ethanol. On the other hand, the species $O$. basilicum contains a significant yield and the extraction of the five preceding chemical elements in the water. The third species, T. algeriensis, does not show a correlation between the extraction yield and the phenol and flavonoid contents because it has a good yield with water but contains only tannins and saponins as well as a significant extraction by the chloroform demonstrates the significant presence of flavonoids.

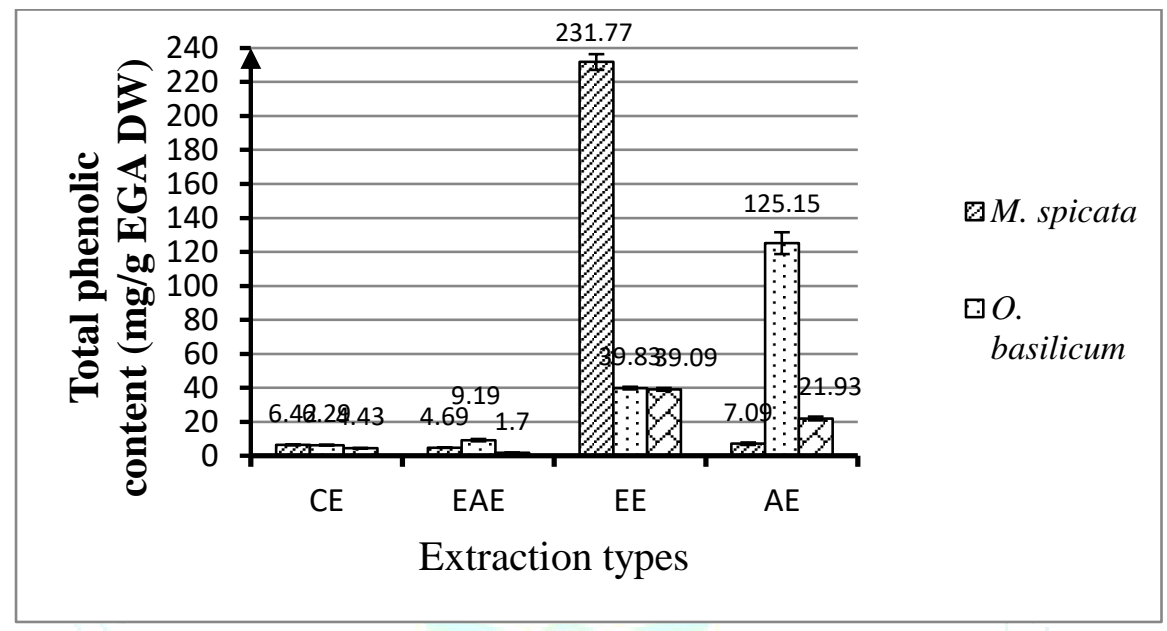

Fig.3: Comparison of total phenolic in three plants.

CE: Chloroform extract ; EAE: Ethyl acetate extract ; EE : Ethanol extract ; AE: Aqueous extract

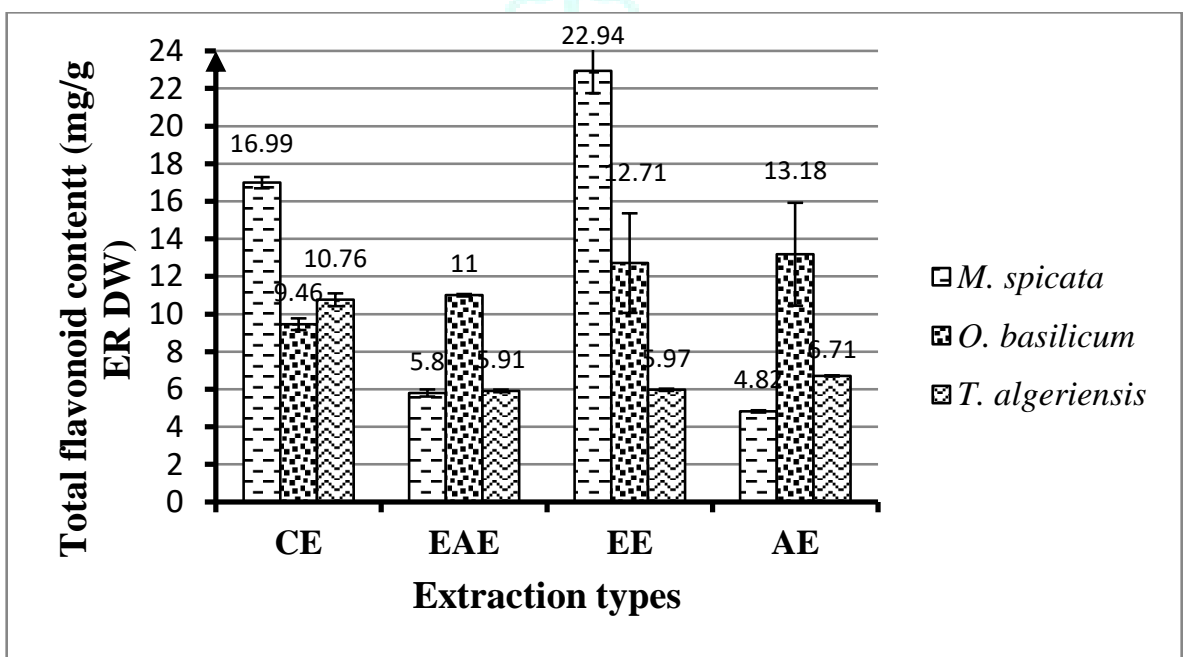

Fig. 4: Comparison of total flavonoid content in three plants.

CE: Chloroform extract; EAE: Ethyl acetate extract; EE: Ethanol extract; AE: Aqueous extract.

\subsection{Comparison of antioxidant activity}

From table 3, we found that the two species M. spicata and T. algeriensis show excellent antioxidant activity in the ethanolic extract according to the two tests (DPPH and ABTS) compared to the ascorbic acid of reference.
On the other hand, 0 . basilicum has antioxidant activity in both solvents (ethanol and water) but with good activity in aqueous extraction. This shows that these three species are excellent producers of antioxidant products where the importance of valuing the Algerian species. 
Tab. 3: Comparison of the antioxidant activity in three plants studied.

CE: Chloroform extract; EAE: Ethyl acetate extract; EE: Ethanol extract; AE: Aqueous extract; NA: No active.

\begin{tabular}{|l|c|c|c|c|c|c|}
\hline & \multicolumn{2}{|c|}{ M. spicata } & \multicolumn{2}{c|}{ O. basilicum } & \multicolumn{2}{c|}{ T. algeriensis } \\
\hline & $\begin{array}{c}\text { DPPH } \\
\text { IC50 }(\mathrm{mg} / \mathrm{ml})\end{array}$ & $\begin{array}{c}\text { ABTS } \\
\text { IC50 }(\mu \mathrm{g} / \mathrm{ml})\end{array}$ & $\begin{array}{c}\text { DPPH } \\
\text { IC50 }(\mathrm{mg} / \mathrm{ml})\end{array}$ & $\begin{array}{c}\text { ABTS } \\
\text { IC50 }(\mu \mathrm{g} / \mathrm{ml})\end{array}$ & $\begin{array}{c}\text { DPPH } \\
\text { IC50 }(\mathrm{mg} / \mathrm{ml})\end{array}$ & $\begin{array}{c}\text { ABTS } \\
\text { IC50 }(\mu \mathrm{g} / \mathrm{ml})\end{array}$ \\
\hline CE & $1.111 \pm 0.002$ & NA & $1.092 \pm 0.003$ & NA & NA & NA \\
\hline EAE & $0.637 \pm 0.019$ & NA & $0.671 \pm 0.032$ & NA & NA & NA \\
\hline EE & $0.007 \pm 0.0005$ & $10.1 \pm 0.79$ & $0.066 \pm 0.007$ & $10.6 \pm 0.14$ & $0.052 \pm 0.004$ & $42 \pm 0.99$ \\
\hline AE & NA & NA & $0.052 \pm 0.001$ & $22 \pm 0.25$ & NA & $152 \pm 31$ \\
\hline Ascorbicacid & $2.10^{-4} \pm 10^{-6}$ & $8.2 \pm 0.40$ & $2.10^{-4} \pm 10^{-6}$ & $8.2 \pm 0.40$ & $2.10^{-4} \pm 10^{-6}$ & $8.2 \pm 0.40$ \\
\hline
\end{tabular}

\section{CONCLUSION}

The present study evaluated the phytochemical constituents and antioxidant activities of three important species of Lamiaceae in Algeria (Mentha spicata, Ocimum basilicum and Thymus algeriensis). We noticed that the M. spicata species contains the largest fraction of phenolic and flavonoid products than the other two species studied. We founded that the two species M. spicata and T. algeriensis show excellent antioxidant activity in the ethanolic extract according to the two tests (DPPH and ABTS) compared to the ascorbic acid of reference. These plants will further evaluated for isolation of their active principles or formulate herbal antioxidant preparations with lesser toxic effects than the synthetic one.

ACKNOWLEDGMENTS: This work was supported by the Algerian Ministry of High er Education and Scientific Research.

CONFLICTS OF INTEREST: The authors declare no conflict of interest.

\section{REFERENCES}

1. Wong $\mathrm{C}$, Cheng $\mathrm{H} \mathrm{Li} \mathrm{K}$ and Chen $\mathrm{F}, \mathrm{A}$ systematic survey of antioxidant activity Chinese medicinal plants using the ferric reducing antioxidant power assay, Food Chemistry, 2006; 97:705-711.

2. Parr AJ, Bolwell PAJ, Phenols in the plant and in man: The potential for possible nutritional enhancement of the diet by modifying the phenols content or profile, Journal of the Science of Food and Agriculture, 2000; 80:985-1012.

3. Carović-StanKo K, Petek M, Martina G, Pintar J, Bedeković D, Ćustić MH, Satovic Z, Medicinal plants of the family Lamiaceae as functional foods-a review. Czech Journal of Food Science, 2016; 34:377-390.

4. Naghibi F. Mosaddegh M. Motamed S. and Ghorbani A. Labiatae, Family in folk Medicine in Iran: from Ethnobotany to Pharmacology, Iranian Journal of Pharmaceutical Research., 2005; 2:63-79.

5. Ozkan M. Glandular and eglandular hairs of Salvia recognita Fisch. \& Mey. (Lamiaceae) in Turkey. Bangladesh Journal of Botany, 2008 ; 37:93-95.

6. Ahmad N, Fazal H, Ahmad I, Abbasi BH, Free radical scavenging (DPPH) potential in nine Mentha species.Toxicology and Industrial Health, $2012 ; 28: 83-89$.

7. Aliakbarlu J, Shameli F, in vitro antioxidant and antibacterial properties and total phenolic contents of essential oils from Tymus vulgaris, $t$. kotschyanus, Ziziphora tenuior and $Z$. clinopodioides. Turkish Journal of Biochemistry, 2013; 38:425431.

8. Oladunmoye M. K, Antioxidant, free radical scavenging capacity and antimicrobial activities of Mirabilis jalapa. Journal of Medcinal Plants Research, 2012; 6(15):2909-2913.

9. Harborne JB. Phytochemical Methods: A Guide to Modern Techniques of Plant Analysis. 3rd ed. London: Academic Press; 1998. P. 193-204.

10. Boulanouar B., Abdelaziz G, Aazza S., Gago C, Miguel, M.G Antioxidant activities of eight Algerian plant extracts and two essential oils, Industrial Crops and Prodocts, 2013; 46:85-96. 